This is the Author-Accepted Manuscript (AAM) version of the following article:

Grappi S., Romani S., Bagozzi R. P. (online publication date: 3 December 2019). The effects of reshoring decisions on employees. Personnel Review. DOI 10.1108/PR-12-2018-0482

The final publication is available at:

https://www.emerald.com/insight/content/doi/10.1108/PR-12-2018-0482/full/html

The AAM is deposited under the Creative Commons Attribution Non-commercial International Licence 4.0 (CC BY-NC 4.0) and any reuse is allowed in accordance with the terms outlined by the licence.

\title{
The effects of reshoring decisions on employees
}

\begin{abstract}
Purpose: We investigate the effects of company decisions to reshore manufacturing activities on employee citizenship behaviors (OCBs). The research considers both company motives for the reshoring decision perceived by employees and gratitude felt toward the organization as antecedents to OCBs.

Design/methodology/approach: We conducted a survey based on a sample of employees belonging to an Italian manufacturing company that had implemented a reshoring decision.

Findings: The employee attributions of intrinsic motives for reshoring and gratitude are shown to positively affect OCBs. Specifically, intrinsic motives influence both OCBIs and OCBOs through the mediating role of gratitude felt by employees, whereas extrinsic motives do not affect, directly or indirectly through mediation of gratitude, OCBs.

Practical implications: Our research illustrates the importance of managing internal communications to employees of company motives for reshoring, which ultimately affect employee gratitude and OCBs.

Originality/value: Our research adds to our knowledge of the effects of reshoring on employees and their relationships with the firms and co-workers and introduces a new area for inquiry.
\end{abstract}

Keywords: Reshoring, gratitude, organization citizenship behaviors, employees

Article classification: Research paper

Acknowledgements: The authors would like to thank Argo Tractors S.p.A. for the precious assistance during the research process. 


\section{Introduction}

We analyze the emerging and increasingly important phenomenon of reshoring practices by manufactures. Manufacturing reshoring (from now on, simply referred to as reshoring) is a company's decision to relocate its activities to the home country, after having implemented an offshoring decision in the past (Ellram, 2013; Gray et al., 2013). Our work complements existing research which has been mainly focused upon public responses to reshoring, and that has not addressed effects on employees of the reshoring firms. We argue that positive evaluations of reshoring by employees can lead to behaviors that benefit the organization and the people in it. We examine reshoring by taking into account the perspective of employees, as important stakeholders in the reshoring organization. No research could be found investigating the effects of reshoring on employees. Reshoring can be conceived as a way to enhance organization citizenship behaviors (OCBs), as well as signal employee support of the organization. Our research shows that employees make attributions (intrinsic vs. extrinsic) of firm motives for reshoring, and this drives both gratitude felt toward the firm and behaviors done benefiting fellow workers.

The incidence of reshoring has recently been recognized (Sirkin et al., 2012), but the consequences of reshoring have not received much attention (Gray et al., 2013; Tate et al., 2014), and only lately has research began to describe and codify reshoring practices (e.g., Dachs and Kinkel, 2013; Kinkel and Maloca, 2009; Kinkel, 2012; Kinkel and Zanker, 2013). A European data base (European Reshoring Monitor: https://reshoring.eurofound.europa.eu/) has been developed consisting of reshoring operations based on secondary data, with the aim of monitoring the phenomenon in Europe. At the same time, studies (Fratocchi et al., 2014; Fratocchi et al., 2016) show that the U.S., Germany, and Italy are the countries most involved in reshoring in recent years. 
Only lately have researchers started to consider the motivations underlying company decisions to reshore. Adopting a firm- or supply-side perspective, current research has identified important firmbased drivers for reshoring, which are largely economic/strategic considerations. Advantages of cost savings have emerged as pivotal factors for decisions to reshore activities from abroad (e.g., Dachs and Kinkel, 2013; Gray et al. 2013; Kinkel, 2012; 2014). Reshoring has also been studied as a way to obtain unique sets of resources and competencies so as to give companies sustainable competitive advantages (e.g., Ancarani et al., 2015; Canham and Hamilton, 2013; Ellram et al., 2013; Wu and Zhang, 2014). By contrast, applying a demand-side perspective, recent research (e.g., Grappi et al., 2015; 2018; Gray et al., 2013) shows also that ethical/moral considerations are useful in understanding public responses to reshoring, which have emerged as critical elements in company value creation. It has been shown, for example, that reshoring positively affects consumers' attitudes towards companies and their willingness to buy/pay for reshored products.

We argue that a need exists to study organization employees as stakeholders, when reshoring decisions are being made. It is important to understand reshoring from an employee's point of view in order to gain a fuller understanding especially of possible positive effects of reshoring for companies. In particular, it is crucial to understand the effects of reshoring decisions on the way employees view their work environment and their attitude toward co-workers. This requires study of the psychological mechanisms by which employees interpret and react to reshoring decisions. In other words, it is important to learn how organization reshoring decisions affect employee behaviors towards the organization, in particular those facilitating organizational functioning and efficiency. In this regard, OCBs are of particular interest (for a review, see Ocampo et al., 2018) and will be of central focus for this study. Although defined variously within the literature (e.g., Borman and Motowidlo, 1993; Organ, 1988; 1997), most OCB definitions share the central idea that employee behaviors (e.g., 
informal mentoring, attendance at company meetings, helping coworkers, and making new employees feel welcome), facilitate organizational functioning, even if they are not expected as part of job descriptions and do not directly impact formal task and firm operations.

Our research examines if, and how organization reshoring decisions promote OCBs. Consistent with the literature (e.g., Williams and Anderson, 1991), OCBs can be divided into behaviors directed mainly at individuals within the organization (OCBIs) and behaviors more concerned with helping the organization as a whole (OCBOs). By focusing on a real case of reshoring and employee responses, our study aims to expand understanding of reshoring in organizational contexts by examining this decision through the perspective of employees, addressing an understudied area in reshoring research. In particular, our research makes the following contributions:

a) it documents, in terms of employee behaviors (i.e., OCBIs and OCBOs), the positive effects of employees' intrinsic attribution of motives to the organization reshoring decision by demonstrating the psychological mechanism through which these positive effects operate, and

b) it shows the key role played by the gratitude felt by employees in driving such a mechanism. The rest of the paper is organized as follows. First, we review key research findings and develop hypotheses based on psychological theories of attributions and emotions. Then we present the results of our study conducted on employees of an organization that actually reshored its activities to the home country. We test our hypotheses on the mechanisms that explain employee behaviors toward the organization following the reshoring decision. The paper ends with a discussion of findings for theory and practice and suggestions for future research.

\section{Conceptual foundations and hypothesis development}

\subsection{Reshoring and employee behavioral responses}


Reshoring and offshoring are location decisions that affect company stakeholders (Ellram et al. 2013; Gray et al. 2013). Research to date has not considered how employees react to reshoring and the mechanisms underlying these reactions. Given the formal connection between reshoring and offshoring (e.g., Grappi et al., 2015), we draw on previous research on offshoring to introduce these mechanisms. The effects of offshoring - both on employees who lose their jobs (i.e., victims) and on employees that retain their jobs after offshoring (i.e., survivors) - have been studied before. Offshoring has clear negative impacts on its victims. Job loss has severe consequences for employees and the public that are economic, physical, cognitive, and emotional (Collins, 1989, Jones, 1991). Job displacement causes personal financial difficulties, as well as loss of personal control, often resulting in depression, poor physical health, and reduced personal functioning (Mencl and May, 2016; Price et al., 2002).

Offshoring can negatively affect survivor work outcomes as well, during the post-offshoring period (Belcourt, 2006; Lopez Bohle et al. 2018; Maertz et al., 2010; Uen et al., 2016). Maertz et al. (2010) investigated offshoring survivors and found that employees feel detached from the organization (because values and goals of the employees and the firm become disjointed), personally threatened, and alienated in the sense that their employer is perceived to be unpatriotic and to have abandoned them.

From an ethical perspective, it seems reasonable to propose that, since survivors went through the layoff process along with victims under offshoring, they directly or vicariously might experience negative feelings from the mistreatment of their coworkers. In this way, they could perceive the organization as intentionally harming employees, thus violating moral standards, engendering righteous anger and creating negative reactions towards itself. 
But what about the analogues practice of reshoring and its effects on current employees? Reshoring also involves ethical/moral issues. These include those connected with the relocation of activities, and consequently jobs, to the home country, together with those connected with the need to stop the exploitation of labor in underdeveloped countries, or to cease taking advantage of lax environmental regulations abroad (Ashby, 2016; Fine, 2013; Grappi et al., 2015; Gray et al., 2013; Smith, 2014). Such positive moral considerations may lead to a favorable evaluation of this decision by employees. In fact, while offshoring can be perceived as causing harm to employees (for both victims and survivors), in reshoring we expect that the organization can be perceived as providing a kind of indirect "help" toward employees. Such indirect help is represented by the fact that the reshoring initiative can be perceived as confirming and facilitating important individual ethical and life goals of employees concerning cooperation, social justice, moral duties, etc. Under reshoring, employees might perceive that the organization endorses ethical standards instead of violating them, helps instead of harms stakeholders, and is worthy of praise and gratitude instead of moral contempt. In other words, although not directly benefited by reshoring, per se, employees might consider it to be an admirable moral decision with which they identify. Thus positive reactions of employees can be expected under reshoring.

Moreover, these positive reactions can be affected further by employee attributions of motives to the company reshoring decisions. Existing research (e.g., Barone et al., 2000; Du et al., 2007; Romani et al., 2016) shows the presence of two primary groups of motives: extrinsic motives, which emphasize the potential benefits to the firm itself; and intrinsic motives, which focus on the potential benefits to people beyond the company. The intrinsic motives are perceived more favorably compared to the extrinsic ones, because they show elements of altruism and enhanced social concern (BeckerOlsen et al., 2006). If individuals infer a company decision to result primarily from extrinsic motives 
(e.g., primarily to increase profits), then they are likely to perceive the company decision less

positively. Conversely, if they attribute a company decision primarily to intrinsic motives (e.g., the desire to take into account the welfare of others in society at large), then they are likely to perceive the company decision more positively, reacting accordingly.

We propose that the motives employees attribute to the organization's decisions to reshore lead to positive responses toward the organization. In our research we focus on specific, discretionary, extra-role behavioral responses, that is, OCBs. OCBs are "employee behaviors that, although not critical to the task or job, serve to facilitate organizational functioning” (Lee and Allen, 2002, p. 132) and for this reason are highly regarded by management. OCBs are extra-role behaviors not formally specified in job descriptions and contrast with in-role behaviors which are formal, expected job duties codified in job descriptions. OBCs also contribute to build employees well-being (Organ, 1988). The literature shows that OCBs can result from employee evaluations related to the organization (e.g., ethical leadership, Zoghbi-Manrique-de-Lara and Viera-Armas, 2017; perceptions of organizational virtuousness, Rego et al., 2010). Two kinds of OCBs have been identified in the literature: OCBIs and OCBOs. The former are OCBs directed to individuals, the latter are OCBs directed to the organization (McNeely and Meglino, 1994). An example of an OCBI is to give time to help others who have workrelated problems, such as volunteering to do the work for an employee needing to be absent. An example of an OCBO is to attend functions that are not required but that can help the organization, such as attending meetings.

\subsection{The mechanism underlying employee behavioral responses: the mediating role of gratitude felt toward the organization}

We draw upon psychological theories of attributions and gratitude to develop our conceptual model and formulate hypotheses. We suggest that, upon becoming aware of reshoring efforts by the 
organization and following inferences of motives, employees perform behaviors benefitting the organization. Our research tries to identify the mechanisms driving such positive reactions.

To present our hypotheses, we first examine the role of attributions by employees concerning perceptions of organization reshoring practices, then we introduce the mediating role of gratitude felt toward the reshoring company and its effect on OCBIs and OCBOs.

Attribution theory (e.g., Weiner 1986) has been underutilized and underappreciated in organizational research, as recently noted by Harvey et al. (2014), despite the considerable contribution it can make. Martinko et al. (2011) also argue that attribution theory represents unrealized potential in organizational research. Attribution theory can be used to examine the processes by which individuals evaluate the motives of others and explains how these perceived motives influence subsequent attitudes and behaviors. Individuals have been found to attribute two primary types of motives to firms: motives that focus on the potential benefit to individuals external to the firm (intrinsic motives) and motives that focus on the potential benefit to the firm itself (extrinsic motives) (Forehand and Grier, 2003). Acknowledging the potential for applying such a conceptualization to the context in hand, we propose that, when employees attribute intrinsic (vs. extrinsic) motivations to organization reshoring decisions, it is likely that this will magnify (vs. weaken) positive reactions toward the organization (i.e., OCBIs and OCBOs) through the mediating role of gratitude felt toward the organization.

Recent research (e.g., Grappi et al. 2015) suggests that motives can be attributed to both intrinsic and extrinsic categories in the reshoring context; stronger intrinsic and weaker extrinsic attributions about the company's motives for reshoring were shown to be associated with higher levels of gratitude. 
Basic research in psychology shows that gratitude results when a person receives tangible or intangible benefits from a benefactor (e.g., McCullough et al., 2001). Further, gratitude depends on concluding that the benefactor intended to do a good deed (Algoe and Haidt, 2009; Emmons, 2003; Tsang, 2006); here gratitude is considered a positive moral emotion (e.g., Algoe and Haidt, 2009; Emmons, 2003). Noteworthy, too, for our research is the fact that gratitude also occurs in situations where desirable aspects of actions by a benefactor are indirectly gratifying and do not require direct, material benefits for the beneficiary. As Ortony et al. (1988) point out, when a person sees that others uphold or surpass the perceiver's moral standards, this itself can constitute a desirable reward to the extent that it facilitates or confirms one's individual goals or values and promotes the occurrence of things one wants to see happen.

Although researchers have specified that a number of organizational events can generate episodic feelings of gratitude (e.g., appreciation programs, contact with beneficiaries, and developmental feedback; Fehr et al., 2017), work to date has been limited to direct rewards mediated by the firm and not indirect rewards residing in good deeds by the organization. When an organization performs a reshoring decision, employees might benefit indirectly and vicariously by judging that the good outcomes produced by the organization are consistent with, and support, their own moral standards and values. They are likely to construe the societal benefits enacted by their employer, embodied in ethical and moral achievements, as facilitating and confirming their own moral interests and goals. This establishes a basis for the moral emotion of gratitude.

In our study, the emotion of gratitude is hypothesized to play an important role in explaining OCBIs and OCBOs. Gratitude not only creates an urge to repay the benefactor in a relationship but in addition promotes prosocial acts more generally and the formation of social bonds (Fredrickson, 2004). McCullough et al. (2001) posit that gratitude functions as a moral motive, inspiring people to 
act in a prosocial manner. Specifically, McCullough et al. argue that the recipient of a benefit who feels gratitude toward a benefactor will be motivated to contribute to the well-being of others. In our research, when employees become aware of the reshoring decision they should feel gratitude toward the organization and, this should instill feeling of giving back to the organization.

Thus, organization-directed gratitude should predict OCBs toward the organization (i.e., OCBOs), because the emotion itself is directed toward the organization. Gratitude elicits a desire to reciprocate and help the moral agent responsible for the benefits received (Bartlett and DeSteno, 2006). Gratitude also can play an instrumental role in facilitating prosocial behaviors and interpersonal exchange (Algoe et al., 2008), and become manifest in positive behaviors towards individuals within the organization (i.e., OCBIs). Consistent with this interpretation, one recent study demonstrated that daily changes in employees' feelings of gratitude are positively associated with daily OCBs (Spence et al., 2014).

Thus it is reasonable to presume that to the extent that the employee values and feels grateful for the decisions of his/her organization, s/he should desire to reciprocate by giving support to the organization. In our study, we hypothesize that gratitude mediates the effects of perceived reshoring motives of the organization on both OCBIs and OCBOs. Here the effects are between the beneficiary of indirect rewards, i.e., the employee, and both coworkers and the organization who are beneficiaries of OCBs. In other words, gratitude motivates other serving acts to third parties (e.g., McCullough et al., 2001). Thus we hypothesize:

H1 gratitude toward the reshoring organization felt by employees will mediate the relationship between perceived company reshoring motives and employee behavioral responses (OCBIs and OCBOs):

H1a: The greater the intrinsic motives, the greater the felt gratitude; 
H1b: The greater the extrinsic motives, the lower the felt gratitude;

H1c: The greater the felt gratitude, the more favorable employees behavioral responses; OCBIs and OCBOs.

\section{Method}

\subsection{Empirical context}

The empirical context of our research is an Italian manufacturing company operating in the mechanical industry and performing as a leader in the production of agricultural machines: Argo Tractors S.p.A. (www.argotractors.com). Argo competes all over the world with one of the widest product lines in the industry. Its production is now based in 4 plants located in the home country. Argo implemented a typical program of full reshoring. In fact, after having experienced production abroad since the early 2000s, about ten years later the company decided to reverse this decision by progressively relocating all its activities back to the home country. At the moment of the data collection (conducted in 2015) the reshoring process had ended. Thus the selected company represents a classic instance of reshoring.

\subsection{Respondents and procedures}

A sample of 266 employees of the reshoring company answered the questionnaire ${ }^{1}$. All the employees of the sample were already working in the organization before the reshoring decision (respondents had been working at the reshoring company for 18 years on average). The sample corresponds to about $15 \%$ of total employees (roughly 1800) in the company; it was selected using a stratified sampling method to represent as much as possible the actual composition of the company's workforce: that is, $71 \%$ blue collar workers, $28 \%$ office workers (including mid-level administrators),

\footnotetext{
${ }^{1}$ In line with Bentler and Chou's (1987) recommendation, and supported by recent simulation studies (e.g., Sideridis et al., 2014; Wolf et al., 2013), the sample size used is adequate for estimating the hypothesized model; the ratio of cases ( $\mathrm{N}=$ 266) to the number of model parameters $(q=43)$ is greater than 5.
} 
and $1 \%$ top managers. Ninety-two percent of the sample was male with an education level of junior high school (29.5\%), high school (60\%) and undergraduate/graduate school (10.5\%). The study was conducted maintaining respondent safety and confidentiality, plus respondents could refuse to participate (44 refused to participate, corresponding to about the $14 \%$ of the employees contacted).

\subsection{Questionnaire development and measures}

A review of the literature and interviews with the company managers were used to specify the conceptual domain of each construct and initial operationalization. The questionnaire was then refined through independent evaluations by four professors and two $\mathrm{PhD}$ students for content and clarity.

Well-established measures were identified from existing research and adapted when possible, to better fit the context at hand. The items measuring intrinsic and extrinsic reshoring motives were derived from the work of Ellen et al. (2006) and Romani et al. (2016). Participants expressed their level of agreement or disagreement on 7-point Likert scales. Three items assessed intrinsic motives and were introduced with the words, "Express your level of agreement with the following statements regarding the reshoring decision of the company": "I think that the company feels morally obligated to reshore its activities back in the home country", "I think that the company has a real, authentic, long term interest in producing in the home country", and "I think that the company really did its best in order to bring back its activities to the home country". Three items assessed extrinsic motives: "I think that the company reshored mainly for economic advantages", "I think that the company reshored mainly to help its own business", and "I think that the company reshored mainly in order to obtain a tax write-off".

A three-item measure of gratitude was developed based on Grappi et al. (2015) and Romani et al. (2013). The items were "I feel grateful for the reshoring decision made by the company", "I feel thankful for the reshoring decision made by the company", and "I appreciate the reshoring decision 
made by the company", with scale anchors of "not at all" (1) and "very much" (7). The measures for employees conducting extra-role behaviors after learning about the organization reshoring decision included 8 items. Four items were used to measure OCBs towards individuals (OCBIs): “Give my time to help others who have work related problems", "Adjust my work schedule to accommodate other employees' requests for time off “, "Go out of the way to make newer employees feel welcome in the workgroup ", and "Assist others with their duties" (Lee and Allen, 2002). Four items were used to assess OCBs towards the organization (OCBOs): "Defend the organization when other employees criticize it", "Show pride when representing the organization in public", "Express loyalty toward the organization", and "Demonstrate concern about the image of the organization" (Lee and Allen, 2002).

\subsection{Validation of measures}

We ran a confirmatory factor analysis (CFA) using LISREL on the relevant items in the model (i.e., intrinsic motives, extrinsic motives, gratitude, OCBI, OCBO) to assess convergent and discriminant validity. The model showed a satisfactory goodness-of-fit (Hu and Bentler, 1999): $\chi 2(109)=259.98 ; \mathrm{CFI}=.97 ; \mathrm{NNFI}=.97 ; \mathrm{RMSEA}=.07 ; \mathrm{SRMR}=.06$. All factor loadings were high and significant which, along with the overall fit, suggests achievement of convergent validity. All construct reliability values were satisfactory, demonstrating acceptable reliability. All the average variances extracted (AVE) were above the recommended threshold of .50, and the Fornell and Larcker criterion and likelihood ratio tests further confirmed that the measures of all variables exhibited discriminant validity (see Table 1). Furthermore, common method variance (CMV) was assessed by controlling for the effects of an unmeasured latent method factor (see Podsakoff et al. 2003). We added to the CFA model a new first-order factor explaining all our measures $(\chi 2(93)=186.99$; RMSEA $=.06 ;$ SRMR $=.03 ; \mathrm{NNFI}=.98 ; \mathrm{CFI}=.98)$. The analysis showed that $\mathrm{CMV}$ is not a major problem in our model; all loadings of the measures on the theoretical latent variables remained 
positive, significant ( $\mathrm{p}$-values < 0.001 ), and statistically stronger compared to the loadings of our measures on the common method factor. Given these results, it is appropriate to move to tests of our main hypotheses.

-- Table 1 about here --

\section{Results}

In order to test hypotheses, we ran the model illustrated in Figure 1 using structural equation modeling (Lisrel 8.80), where each latent variable shown in the figure was indicated by its respective measured items described under Method. The model showed an excellent fit (Hu and Bentler, 1999): $\chi 2(127)=289.18 ; \mathrm{CFI}=.97 ; \mathrm{NNFI}=.97 ; \mathrm{RMSEA}=.06 ; \mathrm{SRMR}=.06$. Results showed a positive and significant influence of the intrinsic motives on gratitude $(b=.54 ; \mathrm{p}<.001)$ supporting H1a, whereas the extrinsic motives did not significantly affect the emotion of gratitude. Thus, H1b is not supported. Gratitude positively affected both OCBIs $(b=.60, p<.001)$ and OCBOs $(b=.59, p<.001)$, supporting H1c. Finally, the direct effect of intrinsic motives on OCBOs was significant $(b=.26 ; p<$ .001), but not on OCBIs. Extrinsic motives do not directly affect OCBIs and OCBOs.

Our study largely confirms the mediation mechanism exerted by gratitude, hypothesized to explain how organization reshoring decisions favor OCBs through employees' attribution of intrinsic motives. Results show that the effect of the employees' attribution of intrinsic motives on OCBIs is fully mediated by the level of gratitude (i.e., the direct effect of the intrinsic motives on OCBIs is nonsignificant: $b=.07, p>.05)$. The effect of the intrinsic motives on OCBOs supports partial mediation, given the significant direct effect of the employees' attributions of intrinsic motives on OCBOs $(b=$ $.26, \mathrm{p}<.001)$. With respect to extrinsic motives, they do not directly affect OCBIs and OCBOs, nor indirectly through the mediation of gratitude. Therefore, the hypothesized role played by gratitude in 
mediating the effects of employee attributions of motives to reshoring on OCBs is supported in the case of intrinsic motives, but not for extrinsic motives.

-- Figure 1 and Table 2 about here -

\section{Discussion}

Our study is one of the first to adopt the employee perspective in examining company reshoring decision. We investigated the experiences of employees in relation to decisions made by their employer with respect to reshoring. Employees react to reshoring initially with judgements of attributions (intrinsic and extrinsic motives). Whereas no effects were found for extrinsic attributions of motives for the organization reshoring decision, the intrinsic attributions were shown to lead to enhanced extra-role (OCBIs and OCBOs) behaviors through the mediating role of gratitude.

Therefore, the processes occurring between formation of intrinsic attributions and extra-role behaviors were found to follow a specific mediation process. Indeed, our research answers the question of how perceived intrinsic reshoring attribution motives influence extra-role behaviors. Specifically, we demonstrated a mechanism through which the employees' intrinsic attributions activate feelings of gratitude toward the organization, and gratitude, in turn, fosters extra-role behaviors. In so doing, this work complements the existing research on reshoring by looking at the effects of reshoring from the employee point of view, showing that employee intrinsic attributions of reshoring motives of the firm can play a role in enhancing behaviors benefiting the organization. Conversely, extrinsic attributions of reshoring motives do not play a mediating role as no effects were found for this construct. This result confirms the positive nature of the reshoring decision that, even though perceived as inspired by extrinsic motivations, it does not decrease the positive returns in terms of employees' evaluations and behaviors here hypothesized. 
Ultimately, our research adds to recently emerging research on reshoring (e.g., Ancarani et al., 2015; Canham and Hamilton, 2013; Dachs and Kinkel, 2013; Ellram et al. 2013; Grappi et al., 2015; 2018; Gray et al. 2013; Kinkel, 2012; 2014) by introducing a new perspective that looks at the point of view of an understudied stakeholder, namely, the employee. In so doing, our work makes new theoretical contributions. First, it offers a richer perspective on the positive returns that reshoring can have for the organization implementing it by suggesting a role for employees' evaluations of reshoring, which should be considered together with other elements identified in the current literature (e.g., appreciation programs or developmental feedback; Fehr et al., 2017) as activators of gratitude in the workplace.

Moreover, our study contributes to current research on positive effects that company decisions (in this case, reshoring) can have for organizations (e.g., Zoghbi-Manrique-de-Lara and Viera-Armas, 2017; Rego et al., 2010). From this point of view, our study uncovers a new route to increasing organization citizenship behaviors (OCBs). The processes promoting OCBs revealed in our research show that OCBs can be fostered through influencing employee attributions of intrinsic motives about reshoring, and subsequently stimulating gratitude as a mediating mechanism.

Our research offers interesting implications for organizations, suggesting that management, to fully understand the benefit of reshoring implementation, should consider it not only from a strategic point of view (e.g., costs evaluation, resources and competences acquisition) but also from the internal perspective of the current employees. In fact, practitioners should be aware of reshoring opportunities as a means for enhancing employees' gratitude and related behaviors benefiting the organization, and should learn how to approach and maximize employee evaluations and consequent reactions of the sort studied herein. 
For organizations that decide to reshore, our study emphasizes the importance to effectively manage internal organization communication (specifically directed toward workers) about this strategic decision in order to make the employees aware of reshoring, giving the important role this decision awareness has in activating virtuous behaviors benefiting the organization and the people in it (i.e., OCBs). Moreover, internal communication campaigns focused on intrinsic attributions for the reshoring decision of the organization should favor positive returns for the organization itself. At the same time, an adequate and consistent coverage in the press for the organization reshoring decision should strengthen the same positive returns.

Our study provides interesting insights we believe into examining reshoring, but a number of limitations should be mentioned. We studied specific mechanisms based on the mediating role of gratitude able to transform employee attributions into behaviors benefiting the organization (i.e., OCBIs and OCBOs), but there are a number of research directions possible to strengthen the contribution of our research for the future. First, the employees' tenure might play a role as a moderator of the mechanisms investigated herein, as it could better qualify the effects of the attributions on gratitude due to experience and, at the same time, of gratitude on OCBs. Again, it would be interesting to go beyond tenure to discover what is behind any effects due to experience, such as differences in knowledge or skills of workers or differences in sensitivities to position in the organization such as power, responsibilities, or vested interests.

An important limitation that should be noted concerns causality. Our study was a crosssectional investigation, and as a result we cannot make claims with respect to causality. It is desirable to either use an experimental methodology and manipulate intrinsic and extrinsic motives or conduct a longitudinal investigation where independent and dependent variable measurements are done at separate points in time, ideally with a cross-lagged panel approach. Another approach to address issues 
of causality, at least partially, would be to compare the model in Figure 1 in two or more settings to test for generalizability or contingencies. We also acknowledge that our sample might have drawbacks and future study could select a larger sample that would reduce the chances of false positives. Finally, connected also with the limitations detailed above, sampling across types of manufacturing firms and in different countries would further verify the scope of the processes in the model.

Still another question concerns the duration and sustainability of the effects of gratitude. If these effects wear off quickly, then the benefits to OCBs might be short-lived. It would be interesting to follow gratitude over time and also investigate situational and personal factors that might sustain it or modulate its effects. For example, in a study of reactions by consumers to reshoring decisions, Grappi et.al (2015) found that ethnocentrism moderated the effects of perceptions of motives of firms on anger towards firms (i.e., consumers were less angry when firms were perceived to be more benevolent and at the same time when consumers were more ethnocentric). Other plausible moderators are animosity toward countries and cultural distance from countries where reshoring originated.

Moreover, it should be acknowledged that our research is based on employees of a single, albeit real, company that reshored all its manufacturing activities. The choice of this research context strengthened the sense of relevance for employees, but at the same time, could have induced unkown biases due to the particular company and industry selected. Future research should address these limitations by replicating and extending the proposed model in different organizations, operating in different industries and also reshoring from different countries. Future research should also investigate organizations that reshored only some of their activities as well as organizations that reshored different functions from manufacturing (e.g., R\&D), in order to verify possible peculiarities in employee perceptions and responses. 
Finally, future research could also investigate other positive moral emotions, such as admiration, elevation, and awe (e.g., Algoe and Haidt, 2009) and incorporate negative moral emotions, such as contempt, righteous anger, and social disgust (e.g., Rozin et al., 1999), that research into corporate social responsibility has shown to influence behavior. Such self-conscious emotions as pride, shame, embarrassment and guilt might also be investigated as motivators of positive or negative reactions towards firms by their employees (e.g., Tracy and Robins, 2007). 


\section{References}

Algoe, S., Haidt, J. and Gable, S. (2008), "Beyond reciprocity: Gratitude and relationships in everyday life", Emotion, Vol. 8 No. 3, pp. 425-429.

Algoe, S. B. and Haidt, J. (2009), "Witnessing excellence in action: The "'Other-Praising', emotions of elevation, gratitude, and admiration”, The Journal of Positive Psychology, Vol. 4 No. 2, pp. 105-127.

Ancarani, A., Di Mauro, C., Fratocchi, L., Orzes, G. and Sartor, M. (2015), "Prior to reshoring: A duration analysis of foreign manufacturing ventures", International Journal of Production Economics, Vol. 169 November, pp. 141-155.

Ashby, A. (2016), "From global to local: Reshoring for sustainability”, Operations Management Research, Vol. 9 No. 3/4, pp. 75-88.

Barone, M. J., Miyazaki, A. D. and Taylor, K. A. (2000), “The influence of cause-related marketing on consumer choice: does one good turn deserve another?", Journal of the Academy of Marketing Science, Vol. 28 No. 2, pp. 248-263.

Bartlett, M. Y. and DeSteno, D. (2006), “Gratitude and prosocial behavior: Helping when it costs you", Psychological Science, Vol. 17 No. 4, pp. 319-325.

Becker-Olsen, K. L., Cudmore, B. A. and Hill, R. P. (2006), “The impact of perceived corporate social responsibility on consumer behavior”, Journal of Business Research, Vol. 59 No. 1, pp. 46-53.

Belcourt, M. (2006), “Outsourcing: The benefits and the risks”, Human Resource Management Review, Vol. 16 No. 2, pp. 269-279.

Bentler, M. P., and Chou, C.P. (1987). Practical Issues in Structural Modeling. Sociological Methods \& Research, 16(1), 78-117. 
Borman, W. C. and Motowidlo, S. J. (1993), "Expanding the criterion domain to include elements of contextual performance”, in Schmitt, N., Borman, W. C. and Associates (Eds.), Personnel selection in organizations, Jossey-Bass, San Francisco, CA. pp. 71-98.

Canham, S. and Hamilton, R. T. (2013), "SME internationalisation: Offshoring, "backshoring”, or staying at home in New Zealand”, Strategic Outsourcing: An International Journal, Vol. 6 No. 3, pp. 277-291.

Collins, D. (1989), “Organizational harm, legal condemnation, and stakeholder retaliation: A typology, research agenda and application”, Journal of Business Ethics, Vol. 8 No. 1, pp. 1-13.

Dachs, B. and Kinkel, S. (2013), "Backshoring of production activities in European manufacturing: evidence from a large scale survey", in Fynes B. and Coughlan P. (Eds), Operations Management at the Hearth of the Recovery, Proceedings of the 20th EurOMA Conference.

Du, S., Bhattacharya, C. B. and Sen, S. (2007), "Reaping relational rewards from corporate social responsibility: the role of competitive positioning", International Journal of Research in Marketing, Vol 24 No. 3, pp. 224-241.

Ellen, P.S., Webb, D. J. and Mohr, L. A. (2006), "Building corporate associations: Consumer attributions for corporate socially responsible programs", Journal of the Academy of Marketing Science, Vol. 34 No. 2, pp. 147-157.

Ellram, L.M. (2013), “Offshoring, reshoring and the manufacturing location decision”, Journal of Supply Chain Management, Vol. 49 No. 2, pp. 3-5.

Ellram, L. M., Tate, W. L. and Petersen, K. J. (2013), “Offshoring and reshoring: An update on the manufacturing location decision”, Journal of Supply Chain Management, Vol. 49 No. 2, pp. 1422. 
Emmons, R. A. (2003), “Acts of gratitude in organizations”, in Cameron, K. S., Dutton, J. E. and Quinn, R. E. (Eds.), Positive organizational scholarship: Foundations of a new discipline, Berrett-Koehler, San Francisco, CA, pp. 81- 93.

Fehr, R., Fulmer, A, Awtrey, E. and Miller, J. A. (2017), “The grateful workplace: A multilevel model of gratitude in organizations", Academy of Management Review, Vol. 42 No. 2, pp. 361-381.

Fine, C. (2013), "Intelli-sourcing to replace offshoring as supply chain transparency increases", Journal of Supply Chain Management, Vol. 49 No. 2, pp. 6-7.

Forehand, M. R. and Grier, S. (2003), "When is honesty the best policy? The effect of stated company intent on consumer skepticism”, Journal of Consumer Psychology, Vol. 13 No. 3, pp. 349-356.

Fratocchi, L., Di Mauro, C., Barbieri, P., Nassimbeni, G. and Zanoni, A. (2014), "When manufacturing moves back: Concepts and questions", Journal of Purchasing and Supply Management, Vol. 20 No. 1, pp. 54-59.

Fratocchi, L., Ancarani, A., Barbieri, P., Di Mauro, C., Nassimbeni, G., Sartor, M., et al. (2016). Motivations of manufacturing reshoring: An interpretative framework. International Journal of Physical Distribution \& Logistics Management, Vol. 46 No. 2, pp. 98-127.

Fredrickson, B. L. (2004), “Gratitude, like other positive emotions, broadens and builds”, in Emmons, R. A. and McCullough M. E. (Eds.), The psychology of gratitude, Oxford University Press, Oxford, UK, pp. 145-166.

Grappi, S., Romani, S. and Bagozzi, R.P. (2015), "Consumer stakeholder responses to reshoring strategies", Journal of the Academy of Marketing Science, Vol. 43 No. 4, pp. 453-471.

Grappi, S., Romani, S. and Bagozzi, R. P. (2018), "Reshoring from a demand-side perspective: Consumer reshoring sentiment and its market effects", Journal of World Business, Vol. 53 No. 2, pp. 194-208. 
Gray, J.V., Skowronski, K., Esenduran, G. and Rungtusanatham, J. M. (2013), “The Reshoring Phenomenon: What Supply Chain Academics Ought to know and Should Do", Journal of Supply Chain Management, Vol. 49 No. 2, pp. 27-33.

Harvey, P., Madison, K., Martinko, M., Crook, T. R. and Crook, T. A. (2014), “Attribution theory in the organizational sciences: The road traveled and the path ahead", The Academy of Management Perspectives, Vol. 28 No. 2, pp. 128-146.

Hu, L. and Bentler, P. M. (1999). Cutoff criteria for fit indexes in covariance structure analysis: Conventional criteria versus new alternatives. Structural Equation Modeling: A Multidisciplinary Journal, Vol. 6 No. 1, pp. 1-55.

Jones, T. M. (1991), "Ethical decision making by individuals in organizations: An issue-contingent model”, Academy of Management Review, Vol. 16 No. 2, pp. 366-395.

Kinkel, S. and Maloca, S. (2009). Drivers and antecedents of manufacturing offshoring and backshoring-A German perspective. Journal of Purchasing and Supply Management, Vol. 15 No. 3, pp. 154-165.

Kinkel, S. and Zanker, C. (2013). New patterns of German production relocation and back shoring activities after the global economic crisis. B. Fynes, and P. Coughlan (Eds.). Operations management at the hearth of the recovery, proceedings of the 20th EurOMA conference.

Kinkel, S. (2014), "Future and impact of backshoring-Some conclusions from 15 years of research on German practices”, Journal of Purchasing and Supply Management, Vol. 20 No. 1, pp. 6365.

Kinkel, S. (2012), "Trends in production relocation and backshoring activities: Changing patterns in the course of the global economic crisis", International Journal of Operations and Production Management, Vol. 32 No. 6, pp. 696-720. 
Lee, K. and Allen, N. J. (2002), “Organizational citizenship behavior and workplace deviance: The role of affect and cognitions", Journal of Applied Psychology, Vol. 87 No. 1, pp. 131-142.

Lopez Bohle, S. A., Chambel M. J., and Iriarte A. D. V. (2018) Job insecurity, procedural justice and downsizing survivor affects, The International Journal of Human Resource Management, DOI: $\underline{10.1080 / 09585192.2018 .1482939}$

Maertz Jr., C. P., Wiley, J. W., LeRouge, C. and Campion, M. A. (2010), “Downsizing effects on survivors: Layoffs, Offshoring, and Outsourcing”, Industrial Relations, Vol. 49 No. 2, pp. 275285.

Martinko, M. J., Harvey, P. and Dasborough, M. T. (2011), “Attribution theory in the organizational sciences: A case of unrealized potential”, Journal of Organizational Behavior, Vol. 32 No. 1, pp. 144-149.

McCullough, M. E., Kilpatrick, S. D., Emmons, R. A. and Larson, D.B. (2001), "Is gratitude a moral affect?”, Psychological Bulletin, Vol. 27 No. 2, pp. 249-266.

McNeely, B. L. and Meglino. B. M. (1994), “The role of dispositional and situational antecedents in prosocial organizational behavior: An examination of the intended beneficiaries of prosocial behavior", Journal of Applied Psychology, Vol. 79 No. 6, pp. 836-844.

Mencl, J. and May, D. R. (2016), “An exploratory study among HRM professionals of moral recognition in off-shoring decisions: The roles of perceived magnitude of consequences, time pressure, cognitive and affective empathy, and prior knowledge”, Business and Society, Vol. 55 No. 2, pp. 246-270.

Ocampo, L., Acedillo, V., Bacunador, A. M., Balo, C. C., Lagdameo, Y. J., and Tupa, N. S. (2018) “A historical review of the development of organizational citizenship behavior (OCB) and its implications for the twenty-first century”, Personnel Review, Vol. 47 No. 4, pp. 821-862. 
Organ, D. W. (1988), “Organizational citizenship behavior: The good soldier syndrome”, Lexington Books, Lexington, MA.

Organ, D. W. (1997), “Organizational citizenship behavior: It's construct clean-up time”, Human Performance, Vol. 10 No. 2, pp. 85-97.

Ortony, A., Clore, G. L. and Collins, A. (1988), The cognitive structure of emotions. Cambridge University Press, New York, NY.

Price, R. H., Choi, J. N. and Vinokur, A. D. (2002), "Links in the chain of adversity following job loss: How financial strain and loss of personal control lead to depression, impaired functioning, and poor health", Journal of Occupational Health Psychology, Vol. 7 No. 4, pp. 302-312.

Podsakoff, P. M., MacKenzie, S. B., Lee, J. and Podsakoff, N. P. (2003), “Common method biases in behavioral research: A critical review of the literature and recommended remedies", Journal of Applied Psychology, Vol. 88 No. 5, pp. 879-903.

Rego, A., Ribeiro, N. and Cunha, M. P. (2010), "Perceptions of Organizational Virtuousness and Happiness as Predictors of Organizational Citizenship Behaviours", Journal of Business Ethics, Vol. 93 No. 2, pp. 215-235.

Romani, S., Grappi, S. and Bagozzi, R.P. (2013), "Explaining Consumer Reactions to Corporate Social Responsibility: The Role of Gratitude and Altruistic Values", Journal of Business Ethics, Vol. 114 No. 2, pp. 193-206.

Romani, S., Grappi, S. and Bagozzi, R.P. (2016), “Corporate socially responsible initiatives and their effects on consumption of green products", Journal of Business Ethics, Vol. 135 No. 2, pp. 253264.

Rozin, P., Lowery, L., Imoda, S. and Haidt, J. (1999), “The CAD triad hypothesis: A mapping between three moral emotions (contempt, anger, disgust) and three moral codes (community, 
autonomy, diversity)", Journal of Personality and Social Psychology, Vol. 76 No. 4, pp. 574586.

Sideridis, G., Simos, P., Papanicolaou, A., and Fletcher, J. (2014). Using Structural Equation Modeling to Assess Functional Connectivity in the Brain Power and Sample Size Considerations. Educational and Psychological Measurement, Vol. 47 No. 5, pp. 733-758.

Sirkin, H., Zinser, M., and Hohner, D. and Rose, J. (2012), "US manufacturing nears the tipping point: which industries? Why, and how much?”, BCG Perspectives, Retrieved June 2, 2018 from: www.bcgperspectives.com/content/articles/manufacturing_supply_chain_management_us_manu facturing_nears_the tipping_point/

Smith, P. (2014), "Flowback or the end of globalization", IIM Kozhikode Society and Management Review, Vol. 3 No. 1, pp. 1-9.

Spence, J. R., Brown, D. J., Keeping, L. M. and Lian, H. (2014), “Helpful today, but not tomorrow? Feeling grateful as a predictor of daily organizational citizenship behaviors", Personnel Psychology, Vol. 67 No. 3, 705-738.

Tate, W. L., Ellram, L., Petersen, K. J. and Schoenherr, T. (2014), “Current practices in offshoring and reshoring", Council Supply Chain Management Professionals, Tobias Schoenherr Council of Supply Chain Management Professionals.

Tsang, J. (2006), "Gratitude and prosocial behaviour: An experimental test of gratitude", Cognition and Emotion, Vol. 20 No. 1, pp. 138-148.

Tracy, J. L. and Robins, R. W. (2007), "Emerging insights into the nature and function of pride", Current Directions in Psychological Science, Vol. 16 No. 3, pp. 147-150. 
Uen, J. F., Chen, S., Chen, H. and Lin, C. (2016), “The effect of employer's moral obligation violation on survivor's commitment: The mediating role of justice climate", Personnel Review, Vol. 45 No. 2, pp. 214-231.

Weiner, B. (1986), An attributional theory of motivation and emotion, Guilford Press, New York. NY. Williams, L. J. and Anderson, S. E. (1991), “Job satisfaction and organizational commitment as predictors of organizational citizenship and in-role behaviors", Journal of Management, Vol. 17 No. 3, pp. 601-617.

Wolf, E. J., Harrington, K. M., Clark, S. L., and Miller, M. W. (2013). Sample size requirements for structural equation models an evaluation of power, bias, and solution propriety. Educational and Psychological Measurement, Vol. 73 No. 6, pp. 913-934.

Wu X. and Zhang F. (2014), "Home or overseas? An analysis of sourcing strategies under competition”, Management Science, Vol. 60 No. 5, pp. 1223-1240.

Zoghbi-Manrique-de-Lara, P. and Viera-Armas, M. (2017), "Does Ethical Leadership Motivate Followers to Participate in Delivering Compassion?", Journal of Business Ethics, https://doi.org/10.1007/s10551-017-3454-1. 
Table 1. Validation of measures and bases for convergent and discriminant Validity

\begin{tabular}{|c|c|c|c|c|c|}
\hline & & \multicolumn{2}{|c|}{ Mean (SD) } & Reliability & AVE \\
\hline Intrinsic motives & & \multicolumn{2}{|c|}{$5.24(.96)$} & .75 & .76 \\
\hline Extrinsic motives & & \multicolumn{2}{|c|}{$4.15(1.12)$} & .64 & .63 \\
\hline Gratitude & & \multicolumn{2}{|c|}{$6.04(.98)$} & .92 & .80 \\
\hline OCBI & & \multicolumn{2}{|c|}{$5.72(.95)$} & .88 & .64 \\
\hline OCBO & & \multicolumn{2}{|c|}{$5.81(1.06)$} & .92 & .71 \\
\hline \multicolumn{6}{|c|}{ Correlation between variables (standard errors) } \\
\hline & $\begin{array}{l}\text { Intrinsic } \\
\text { motives }\end{array}$ & $\begin{array}{l}\text { Extrinsic } \\
\text { motives }\end{array}$ & Gratitude & OCBI & OCBO \\
\hline Intrinsic motives & 1.00 & & & & \\
\hline Extrinsic motives & $-.22 * *(.06)$ & 1.00 & & & \\
\hline Gratitude & $.53 * * *(.06)$ & $-.11(.08)$ & 1.00 & & \\
\hline OCBI & $.38 * * *(.05)$ & $-.09(.09)$ & $.62 * * *(.08)$ & 1.00 & \\
\hline OCBO & $.58 * * *(.07)$ & $-.12(.09)$ & $.72 * * *(.09)$ & $.67 * * *(.09)$ & 1.00 \\
\hline
\end{tabular}

Note: $* * \mathrm{p}$-value $<.01 ; * * * \mathrm{p}$-value $<.001$. 
Table 2. Results for structural equation model analysis

\begin{tabular}{|c|c|c|}
\hline Measurement Model & Std. loading & $t$-value \\
\hline \multicolumn{3}{|l|}{ Intrinsic motives } \\
\hline I think that the company feels morally obligated to reshore its activities back in the home country & .65 & -- \\
\hline I think that the company has a real, authentic, long term interest in producing in the home country & $.89 * * *$ & 7.16 \\
\hline I think that the company really did its best in order to bring back its activities to the home country & $.86^{* * *}$ & 7.15 \\
\hline \multicolumn{3}{|l|}{ Extrinsic motives } \\
\hline I think that the company reshored mainly for economic advantages & .76 & -- \\
\hline I think that the company reshored mainly to help its own business & $.67 * * *$ & 5.30 \\
\hline I think that the company reshored mainly in order to obtain a tax write-off & $.62 * * *$ & 5.22 \\
\hline \multicolumn{3}{|l|}{ Gratitude } \\
\hline I feel grateful for the reshoring decision made by the company & .88 & -- \\
\hline I feel thankful for the reshoring decision made by the company & $.93 * * *$ & 21.42 \\
\hline I appreciate the reshoring decision made by the company & $.86 * * *$ & 18.72 \\
\hline \multicolumn{3}{|l|}{$O C B I$} \\
\hline Give my time to help others who have work related problems & .83 & -- \\
\hline Adjust my work schedule to accommodate other employees' requests for time off & $.79 * * *$ & 14.30 \\
\hline Go out of the way to make newer employees feel welcome in the workgroup & $.81 * * *$ & 14.79 \\
\hline Assist others with their duties & $.80 * * *$ & 14.71 \\
\hline \multicolumn{3}{|l|}{$O C B O$} \\
\hline Defend the organization when other employees criticize it & .87 & -- \\
\hline Show pride when representing the organization in public & $.88 * * *$ & 19.59 \\
\hline Express loyalty toward the organization & $.88 * * *$ & 19.56 \\
\hline Demonstrate concern about the image of the organization & $.80^{* * *}$ & 16.28 \\
\hline Paths hypothesized in the Model & Std. loading & t-value \\
\hline Intrinsic motives $\rightarrow$ Gratitude & $.54 * * *$ & 5.64 \\
\hline Extrinsic motives $\rightarrow$ Gratitude & .01 & .16 \\
\hline Gratitude $\rightarrow$ OCBI & $.60 * * *$ & 8.09 \\
\hline Gratitude $\rightarrow$ OCBO & $.59 * * *$ & 9.33 \\
\hline Intrinsic motives $\rightarrow$ OCBI & .07 & 1.03 \\
\hline Extrinsic motives $\rightarrow$ OCBI & -.01 & -.14 \\
\hline Intrinsic motives $\rightarrow$ OCBO & $.26 * * *$ & 3.74 \\
\hline Extrinsic motives $\rightarrow$ OCBO & .00 & .09 \\
\hline
\end{tabular}

Note: $* * *$ p-value $<.001$. 
Figure 1. Summary of results

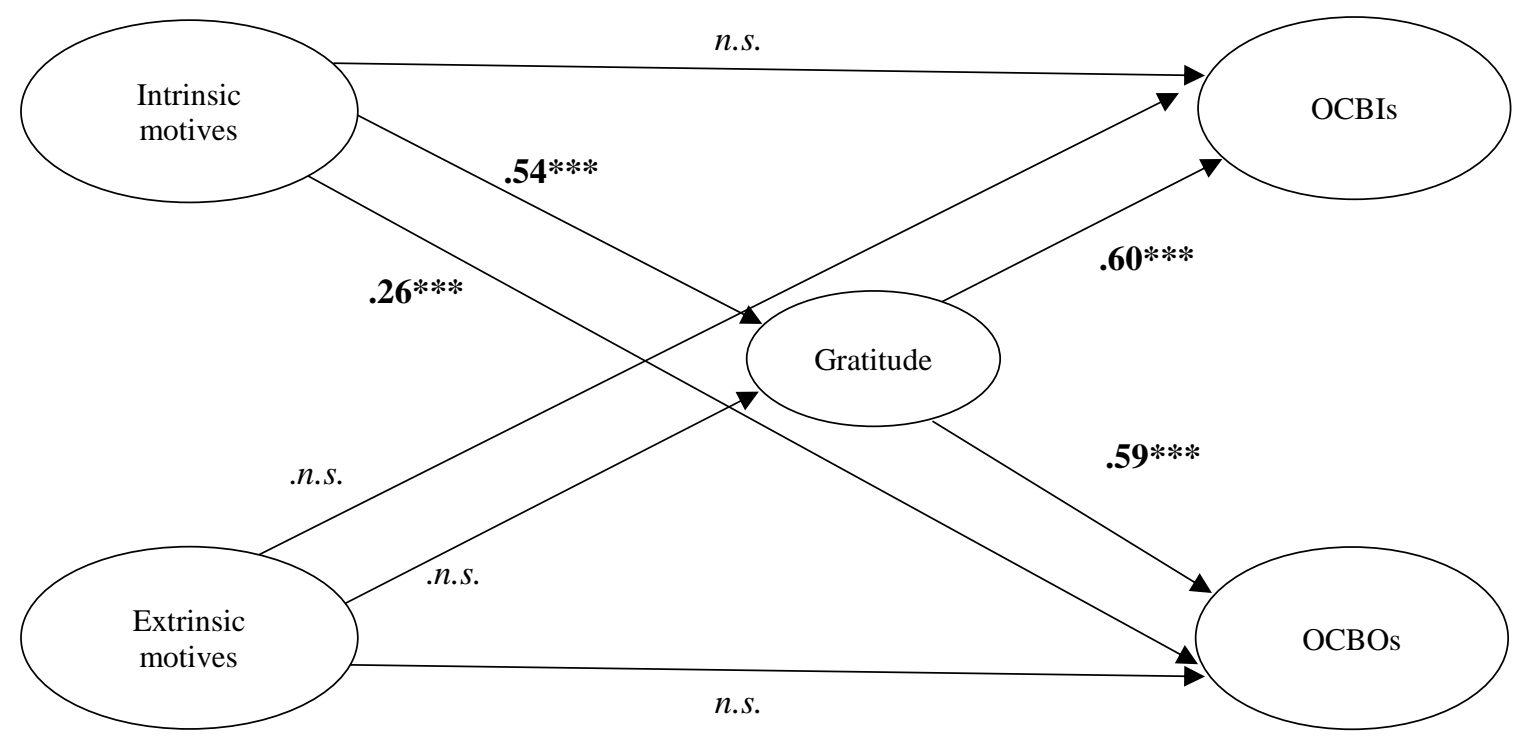

Note: $* * * \mathrm{p}$-value $<.001$. 